\title{
CURRENT STATE OF DEEP OCEAN BATHYMETRIC EXPLORATION
}

\begin{abstract}
The paper presents current state of bathymetric survey concerning deep ocean rather than shallow areas, which are better surveyed due to safety of navigation concerns. Rules and requirements of the new challenge, called the Shell Ocean Discovery XPRIZE, became a starting point for a discussion about the possibilities of mapping large areas of the ocean using up-to-date and new technology. The amount of bathymetric data available nowadays and the current state of ocean map compilations are also discussed in the paper as a motivation to inspire the new initiatives in the deep ocean.
\end{abstract}

\section{Keywords:}

bathymetry, ocean, multibeam echosounder, AUV, ASV, satellite altimetry, bathymetric map compilation.

\section{INTRODUCTION}

The XPRIZE Foundation, a non-profit organization manages a series of competitions encouraging technical development, has recently announced a new challenge, called the Shell Ocean Discovery XPRIZE. An award of 4 million dollars is offered for a team that presents the best technology to map a specific area of the ocean floor within a certain amount of time [10]. Let us take a closer look at the requirements.

According to the Competition Guidelines [5] 'in Round 1, teams must prove they can map the sea floor at a depth of 2.000 meters. In Round 2, teams must 
prove they can map the sea floor at a depth of 4.000 meters. During the testing for each Round, XPRIZE will designate a Competition Area within a 500 square kilometer area of the ocean. The bathymetric map must be at a minimum horizontal resolution of 5.0 meters ( $x$ and y coordinates) and a minimum vertical resolution of 0.5 meter ( $\mathrm{z}$ coordinate)'. At least $20 \%$ of the designated area for Round I and $50 \%$ for Round II must be mapped within respectively 16 hours and 24 hours to fulfill the competition requirements. In addition: all the equipment used by each team must fit into one standard intermodal 40 feet shipping container, mapping device(s) must be launched from shore, and no human is allowed within a competition area.

Deas it really sounds so difficult? Portions of the ocean floor have been mapped during various cruises. So why does the XPRIZE Foundation want to pay 7 million dollars for this? And how much do we really know about the ocean floor, and why does this make a $5 \mathrm{~m}$ by $5 \mathrm{~m}$ resolution so attractive?

\section{RESOLUTION ANALYSIS}

Let us assume we exploit a multibeam echosounder with a typical beamwidth of $1^{\circ}$ mounted on a surface vessel. From simple geometry: at the depth of $2.000 \mathrm{~m}$ we are able to achieve $35 \mathrm{~m}$ of cross-track resolution in the nadir zone, getting worse closer to the swath boundaries, using traditional equal-angle geometry. At $4.000 \mathrm{~m}$, our best achievable resolution decreases to $70 \mathrm{~m}$. Now, the required $5 \mathrm{~m}$ sounds more challenging.

Can $5 \mathrm{~m}$ resolution be considered as good? It depends of a purpose. It is absolutely not acceptable resolution for safety of navigation purposes, but we are not talking about shallow waters and constrained depths. We are talking about deep ocean. For ocean scales maps this resolution is exponentially better than what we currently collect using traditional technology.

As mentioned above, it is impossible to achieve such a resolution of bathymetric data using typical multibeam echosounder mounted on a surface vessel. So what can be done? First thought: improve the hydroacoustic equipment. Such development are constantly undertaken by hi-tech industry, but in terms of deep ocean survey, the law of the physics is what limits the performance of bathymetric data collection. The second and obvious idea is to take hydroacoustic devices 
closer to the ocean floor. This approach is put into practice now by constructing a variety of AUVs (Autonomic Underwater Vehicles) and ROVs (Remotely Operated Vehicles) equipped with multibeam echosounders, side scan sonars and a variety of sensors providing many kinds of data describing the ocean environment. Again, it sounds perfect, but new problems appear. Closer distance from the seafloor results in narrower swath widths. This, together with typically slower speeds of AUV and ROVs, gives much smaller coverage rates, compared to the traditional surface survey vessel. In addition, there is always a portion of risk of equipment loss - in case of AUVs there is no physical connection between underwater device and surface vessel - and this must be considered. Underwater positioning is another issue. Additional acoustic devices utilizing sophisticated computational algorithms must be used to ensure accurate positions of obtained soundings. So data collection using an underwater vehicle in general is slower, more difficult to perform and connected with a particular risk, but does provide high-resolution data from deep water environments.

\section{MODERN APPROACH}

A multibeam echosounder (MBES) is considered as the most reliable source of measuring water depths. Those devices have been used for bathymetric survey 'for 40 years and still only about $12 \%$ of deep ocean has been mapped with MBES — Why?' — asked Larry Mayer during the Forum for Future Ocean Floor Mapping in Monaco in June 2016 [Mayer L., 2016]. And he answered: Because of "physics — tradeoffs between propagation, resolution and system size, belief that deep ocean is boring and uninteresting and cost - systems are not cheap - shiptime even more costly.' If we add a factor of poor resolution of a system mounted on a survey vessel, the need for an alternative system appears.

Let us take a closer look into some examples of AUVs (Autonomous Underwater Vehicles) intended for deep ocean exploration. Woods Hole Oceanographic Institution (WHOI) operates an AUV called 'Sentry', a $2.9 \mathrm{~m}$ long device capable of collecting data down to $6000 \mathrm{~m}$. 'Sentry' weights $1.250 \mathrm{~kg}$, its operating range is constrained to about $100 \mathrm{~km}$ and maximum operating speed reaches about $2.3 \mathrm{kn}$. Ultra-Short Baseline (USBL) Navigation with real-time Acoustic Communications, Long Baseline (LBL) using acoustic transponders, Doppler 
Velocity Log (DVL) and Inertial Navigation System (INS) are used for the AUV's navigation. According to the WHOI website [21] 'Sentry is equipped with a standard suite of scientific and engineering sensors. In addition, Sentry is a sufficiently flexible platform that additional sensors can be interfaced according to specific interests and scientific needs. All sensors are rated to 6,000 meters except as noted.' A Reson 7125 multibeam mapping sonar, Edgetech chirp subbottom profiler and three high precision, digital, 3-axis fluxgate magnetometers are available as geophysical sensors providing the possibility to collect data for bathymetric maps [21].

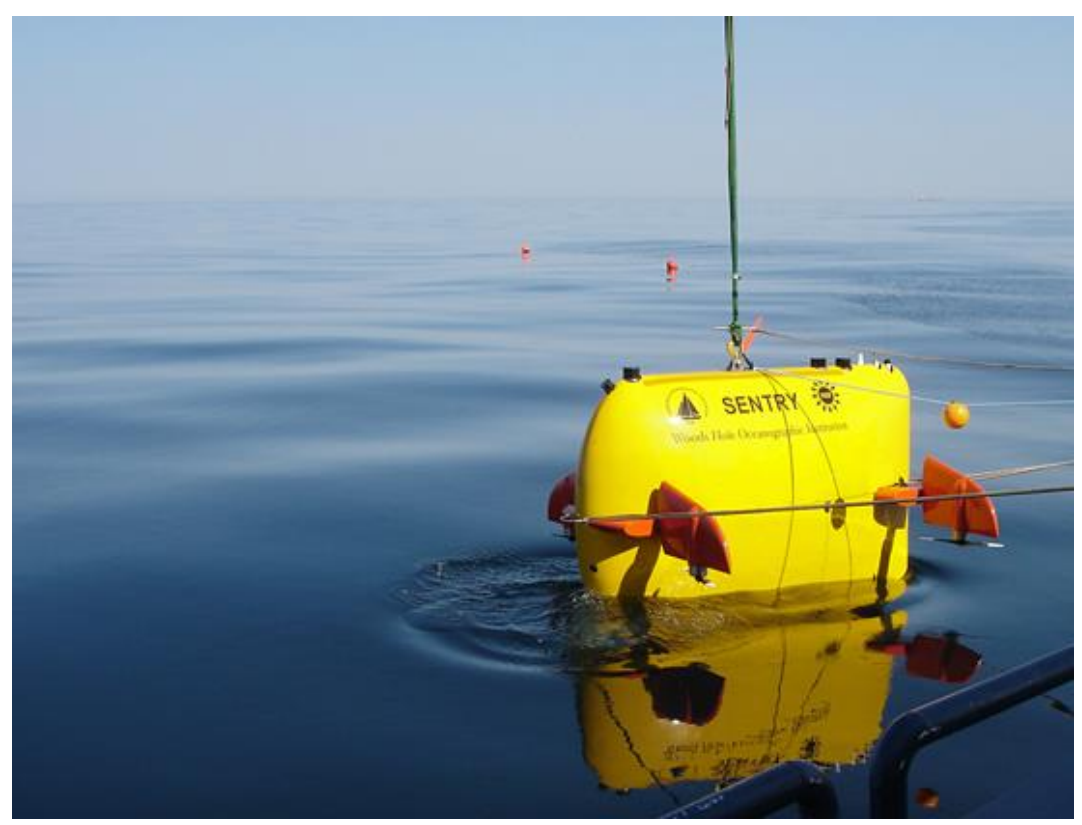

Fig. 1. The AUV 'Sentry' during deep water tests in North Atlantic in 2008 [https://www.whoi.edu/page.do?pid=38095\&\&tid=7842\&cid=39036, photo by Chris German]

'Autosub 6000' is an AUV constructed in National Oceanographic Institution (NOC) in the United Kingdom. According to marketing material [McPhail S., 2009]: 'With an ultimate range up to $1.000 \mathrm{~km}$, a maximum operating depth of $6.000 \mathrm{~m}$, and a generous payload capacity, Autosub 6000 is well placed to become one of the world's most capable deep diving Autonomous Underwater Vehicles'. 


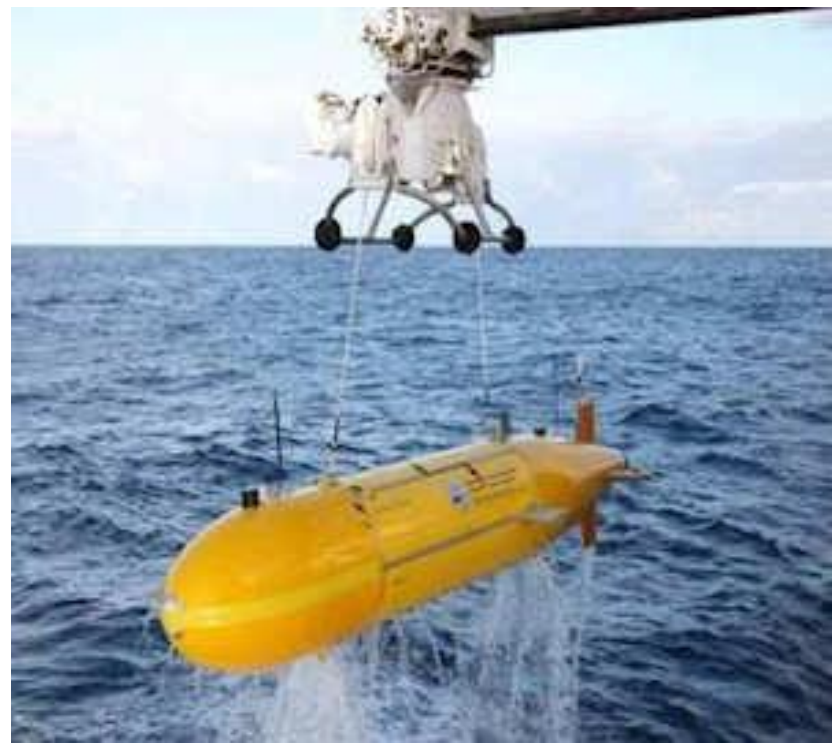

Fig. 2. 'Autosub 6000' constructed in National Oceanographic Institution [http://auvac.org/configurations/view/86]

Kongsberg Maritime offers an AUV called 'HUGIN', available in different configurations with main depth ratings of $3.000 \mathrm{~m}, 4.500 \mathrm{~m}$ and $6.000 \mathrm{~m}$. HISAS (High Resolution Interferometric Synthetic Aperture Sonar) rated to 3.000 m, EM2040 multibeam echosounder, sidescan sonar, sub-bottom profiler, still-image camera, turbidity sensor, acoustic doppler current profiler (ADCP) and methane sensor are just examples of the sensors the vehicle can be equipped with [19].

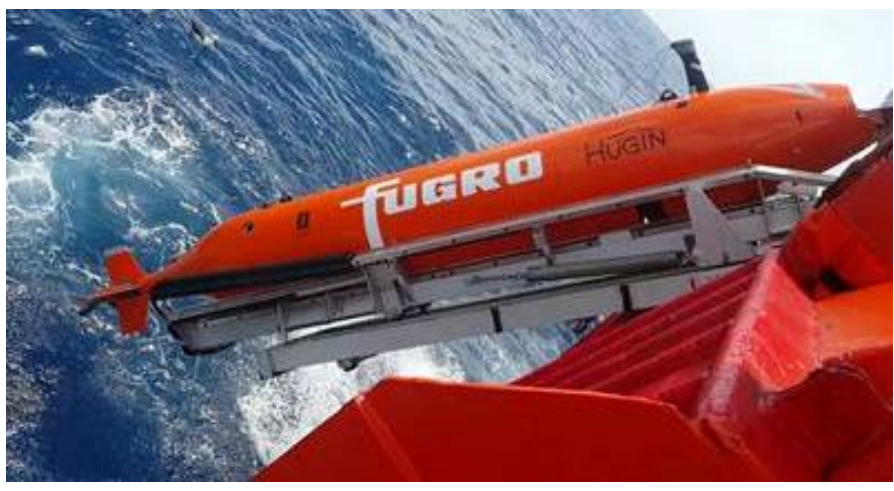

Fig. 3. Kongsberg's 'HUGIN 'operated by Fugro

[http://www.marinetechnologynews.com/news/flight-mh370-latest-fugro-510305] 
Other deep water AUVs operated over the world include, for example the BLUEFIN-21 offered by General Dynamics [12], Explorer class AUVs from International Submarine Engineering [13], REMUS 6000 by Kongsberg [18] and Seafloor Mapping AUVs from MBARI [15].

As described, there are a range of systems capable to take mapping devices closer to the seafloor and enabling higher resolution bathymetric mapping. But, according to [McPhail S., 2009] 'the field is still in its youth and there is relatively little published literature on the science results of deep AUV missions beyond $3.000 \mathrm{~m}$ deep.'

\section{OCEAN MAPPING UP TO DATE}

If deep ocean bathymetric data collection is so difficult, what do we really know about the ocean bathymetry today? And what does a general audience know about it? The common opinion is that global seafloor topography is well known, after all, we all can see it on Google Earth. David Monahan mentions in his book [Monahan D., 2013]: 'One of my colleagues works for the Defense Mapping and Intelligence Agency. She lives in one of the suburbs that surround Washington along with many government employees. When she tells her neighbors that she maps the seafloor, they don't believe her - they are convinced that mapping is a cover story and she's using it to disguise her real profession, which they collectively believe is some sort of spying or intelligence work. They don not believe the seafloor has not been mapped because they have seen maps that look like they are complete'. The Google Earth Map seems complete, with no 'holes' in it. But what data is this really? Google maps and similar ocean bathymetric maps are in fact largely based on interpolation between points and areas of known (mean measured) bathymetry. The question is: what portion of global datasets is measured and what portion is interpolated (mean 'calculated'). Harper and Sharman claimed in [Harper B., Sharman G., Project 1903-2003] 'even today, only the order of $10 \%$ of the seafloor has been measured with direct echosounding'. We are not sure, is it $10 \%$ or $5 \%$ or $15 \%$, but we can be sure it is such a small portion of the seafloor, that the ocean is in fact largely unexplored.

One of the biggest global bathymetric databases is managed by National Centers for Environmental Information (NCEI) - a part of NOAA (National Oceanic and Atmospheric Administration of U.S. Department of Commerce) 
located in Boulder, $\mathrm{CO}$ [20]. Bathymetric data are obtained during various survey cruises lead by different organizations and provided to NCEI, where the data are checked for their quality and made public. Database stores not only multibeam data but also single beam - trackline - soundings. Data are available in various formats - raw multibeam records or processed digital terrain models - depending on data supplier's conditions and always accompanied with detailed metadata. Everything made public by NCEI can be downloaded for free, which is essential for bathymetric maps compilation and other applications.

So how much bathymetric data of the oceans is really available for map making? A first look over the bathymetric data viewer on NCEI website [9] suggests that the situation is really good, large areas of the oceans are covered with survey tracks (Fig. 4).

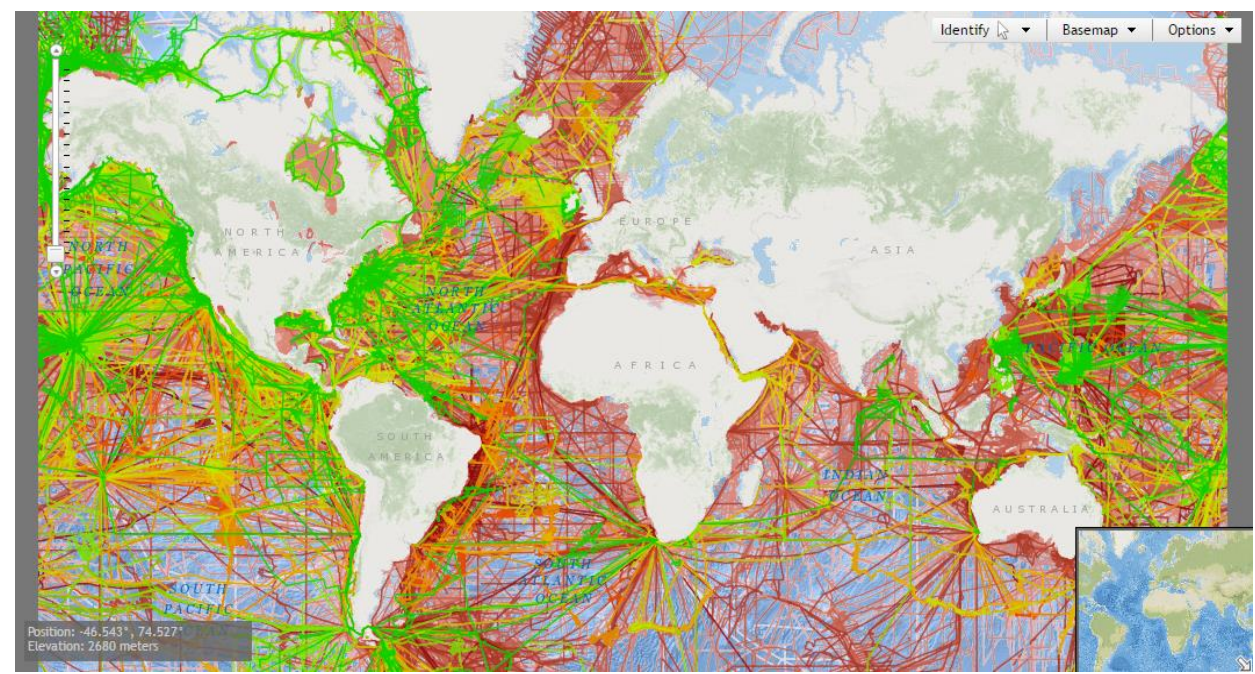

Fig. 4. Multibeam and single-beam bathymetric surveys present in data viewer on NCEI website [http://maps.ngdc.noaa.gov/viewers/bathymetry/]

But, we have to remember about scale. Zooming into any area shows in fact how sparse those data really are. Figure 5 shows an example - the area southwest from Cape Verde, with areas several hundreds of kilometers wide completely unexplored by echosounding. 


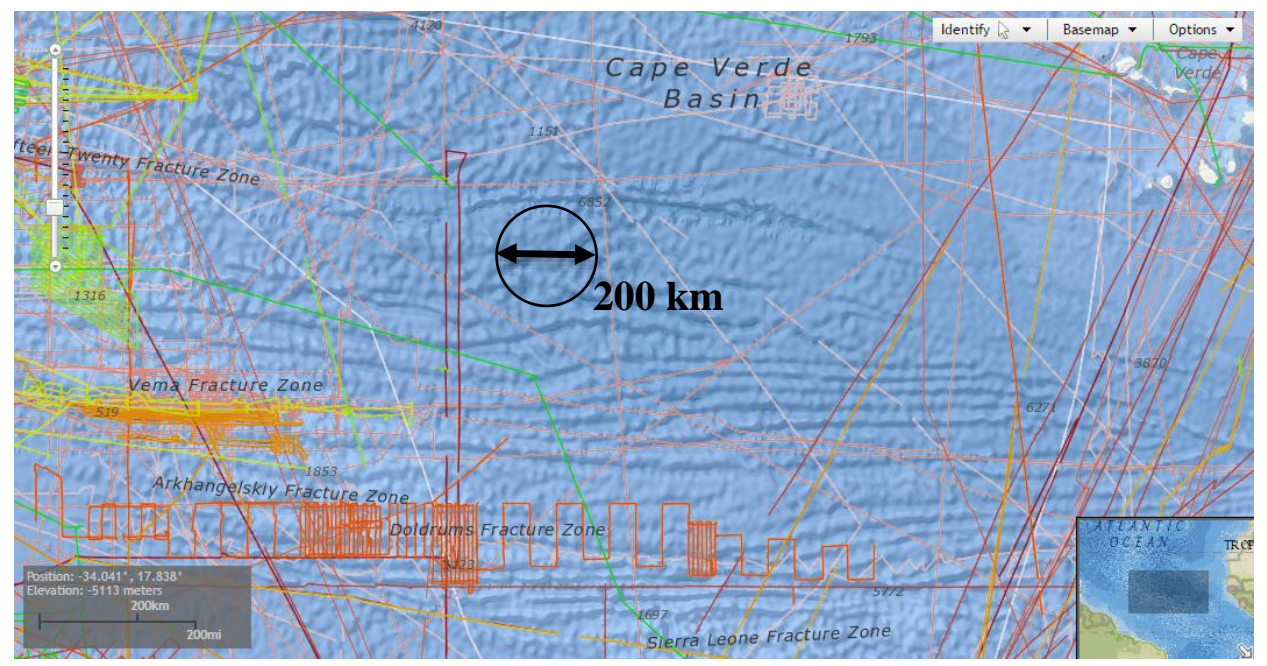

Fig. 5. Multibeam and single-beam bathymetric surveys present in data viewer on NCEI website - the area southwest from Cape Verde; a circle of $200 \mathrm{~km}$ diameter added for scale reference [http://maps.ngdc.noaa.gov/viewers/bathymetry/]

Is echosounding the only source of knowledge about seafloor relief? No, it is not. Information about large features on the deep ocean floor can be also retrieved using a technique called satellite altimetry. The fundamentals of this technique and its application in ocean mapping are straightforwardly explained on NOAA NESDIS STAR (NOAA Satellite and Information Service — The Center for Satellite Applications and Research) website [16]: 'We use satellite radar altimeter measurements of the ocean surface height (sea level) to infer the presence of mountains below. Mountains on the sea floor add extra pull to Earth's gravity field, drawing more water around them and bulging the sea surface outward. An undersea mountain has to be about a mile high and several miles wide in order to generate enough of a bump in sea level to be recognizable in current radar altimeter data. Therefore altimetric bathymetry is not as accurate or detailed as echo sounding from ships. Even so, because altimeter satellites cover the whole Earth, while ships have mapped only a few percent, the best global bathymetric models combine conventional echosoundings with altimetric bathymetry. Our research led to a bathymetric model that has been widely used in the scientific community for more than a decade, and was recently incorporated into GEBCO products and the popular web application Google Earth.' Our understanding of modern compilations such as the global publically-available GEBCO grid [23] and the popular web-application Google Earth are examples of such combined bathymetric models, 
with only $18 \%$ of GEBCO $201430 \operatorname{arcsec}(\sim 1.000 \mathrm{~m})$ grid nodes constrained by data, with remaining nodes reflecting interpolated data based on satellite altimetry [11].

One of the most popular ocean seafloor depictions obtained by a satellite altimetry technique is by Smith and Sandwell [Smith W., Sandwell D., 1997] presented in Figure 6.

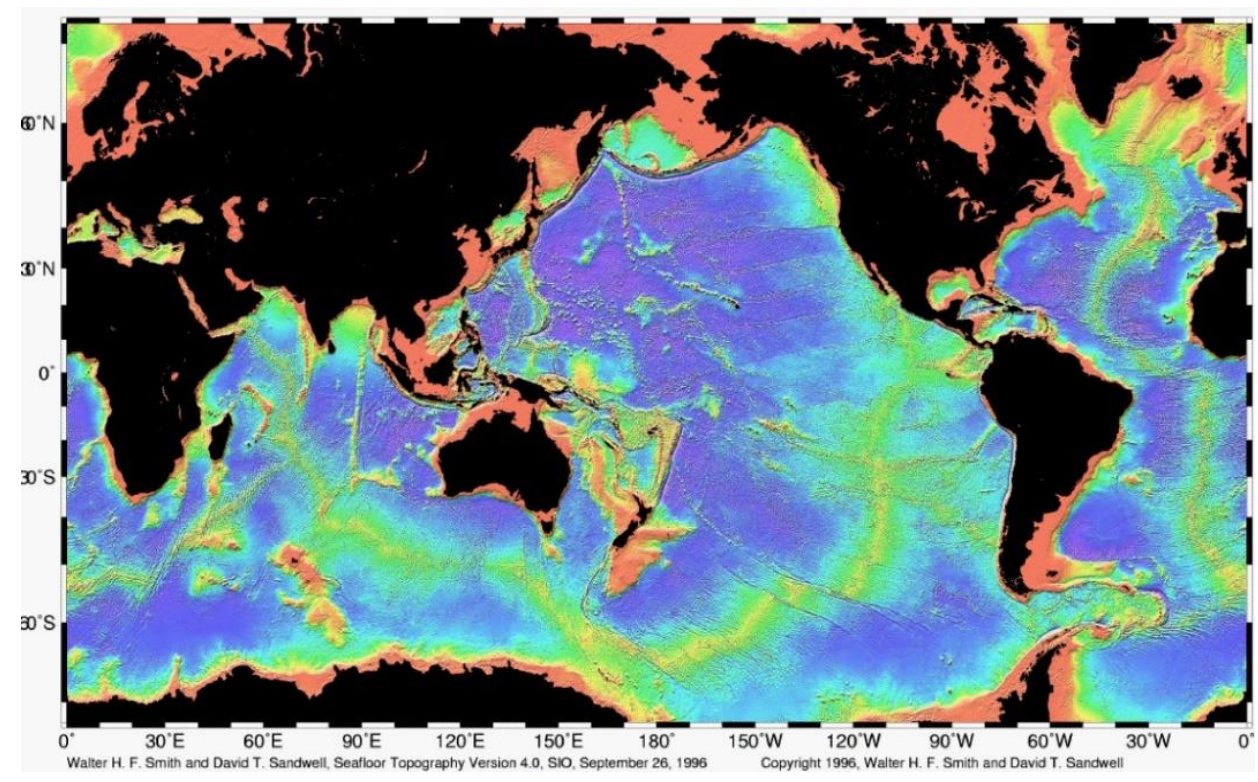

Fig. 6. Measured and Estimated Seafloor Topography

[Smith W., Sandwell D., 1997]

The methodology of this map compilation is described in [Smith W., Sandwell D., Science, 1997]. Authors also pointed out the problems connected with satellite altimetry. First of all 'the topography/gravity ratio varies from one region to another because of changes in sediment thickness and other factors, so that the estimation of topography from gravity is not straightforward and requires accurate depth soundings for calibration' [Smith W., Sandwell D., Science, 1997]. What is more, the horizontal resolution of gravity data, which is a fundament of altimetry deduction, is limited to $20-25 \mathrm{~km}$ ! To sum up, even after combining the satellite data with direct echosounding, there are still large areas completely unexplored or where deducted depths are very uncertain. 


\section{WHY DO WE NEED AN OCEAN BATHYMETRY?}

We are all in agreement about the importance of shallow areas mapping, where it is critical for the safety of navigation. But do we really need to put an effort into expanding our knowledge about the deep ocean? 'Knowledge of ocean floor topography data is essential for understanding physical oceanography, marine biology, chemistry, and geology' - claim Smith and Sandwell in [Smith W., Sandwell D., Science, 1997]. Practical aspect such as tsunami propagation prediction, better understanding of environment and marine resources or law of the sea application can be added to the [17]. And, last but not least, we are simply curious. Is it acceptable that we know Moon and Mars better that our own planet?

\section{REFERENCES}

[1] Harper B., Sharman G., Leadline to multibeam, sextant to GPS \& crow quill to computer: bathymetric data collection, compilation, archiving and distribution in the past century, Charting the Secret Floor of the Ocean Floor, The GEBCO Project 1903-2003, [online], http://www.gebco.net/about_us/presentations_and_publications/documents/ cen_conf_abstract_harper_sharman.pdf [access 11.09.2016].

[2] Mayer L., Such a Big Ocean but our Footprints are so Small (Sonar Footprints), Forum for Future Ocean Floor Mapping, Monaco, June 29, 2016.

[3] McPhail S., Autosub 6000: A Deep Diving Long Range AUV, 'Journal of Bionic Engineering', 2009, Vol. 6, Issue 1, pp. 55-62.

[4] Monahan D., All Bathymetry is Predicted Bathymetry, 2013, manuscript.

[5] Shell Ocean Discovery Xprize Competition Guidelines, [online], http://oceandiscovery. xprize.org/sites/default/files/shell_ocean_discovery_xprize_final_guidelines.pdf [access 11.09.2016].

[6] Smith W., Sandwell D., Global seafloor topography from satellite altimetry and ship depth soundings, 'Science', 1997, Vol. 277, pp. 1957-1962.

[7] Smith W., Sandwell D., Measured and Estimated Seafloor Topography, World Data Service for Geophysics, Boulder Research Publication RP-1, poster, 34" X 53", 1997.

[8] http://auvac.org/configurations/view/86 [access 11.09.2016].

[9] http://maps.ngdc.noaa.gov/viewers/bathymetry/ [access 13.09.2016].

[10] http://oceandiscovery.xprize.org/ [access 11.09.2016].

[11] http://onlinelibrary.wiley.com/doi/10.1002/2015EA000107/pdf [access 11.09.2016]. 
[12] http://www.bluefinrobotics.com/vehicles-batteries-and-services/bluefin-21 [access 11.09.2016].

[13] http://www.ise.bc.ca/auv.html [access 09.09.2016].

[14] http://www.marinetechnologynews.com/news/flight-mh370-latest-fugro-510305 [access 11.09.2016].

[15] http://www.mbari.org/at-sea/vehicles/autonomous-underwater-vehicles/ [access 11.09.2016].

[16] http://www.star.nesdis.noaa.gov/sod/lsa/AltBathy/ [access 13.09.2016].

[17] https://seabed2030.gebco.net/documents/seabed_2030_roadmap_v10_low.pdf [access 11.09.2016].

[18] https://www.km.kongsberg.com/ks/web/nokbg0240.nsf/AllWeb/481519DA1B0207 CDC12574B0002A8451?OpenDocument [access 11.09.2016].

[19] https://www.km.kongsberg.com/ks/web/nokbg0240.nsf/AllWeb/B3F87A63D8E419 E5C1256A68004E946C?OpenDocument [access 11.09.2016].

[20] https://www.ncei.noaa.gov/ [access 13.09.2016].

[21] https://www.whoi.edu/main/sentry/specifications-sensors [access 11.09.2016].

[22] https://www.whoi.edu/page.do?pid=38095\&\&tid=7842\&cid=39036 [access 11.09.2016].

[23] www.gebco.net [access 11.09.2016].

Received September 2016

Reviewed September 2017

Published 30.12.2017

KAROLINA ZWOLAK

Polish Naval Academy

Śmidowicza 69 Str., 81-127 Gdynia, Poland

k.zwolak@amw.gdynia.pl

\section{ANDRZEJ FELSKI}

Polish Naval Academy

Śmidowicza 69 Str., 81-127 Gdynia, Poland

a.felski@amw.gdynia.pl

\section{STRESZCZENIE}

W artykule przedstawiono obecny stan pomiarów batymetrycznych głębokowodnych obszarów oceanicznych. Zasady najnowszego konkursu Shell Ocean Discovery XPRIZE stały się punktem wyjścia do dyskusji o obecnych możliwościach pozyskiwania danych niezbędnych do tworzenia map oceanów w oparciu o aktualnie dostępne technologie. W artykule poruszono również zagadnienie ilości i cech danych batymetrycznych znajdujących się i udostępnianych w bazach danych gromadzących tego typu informacje. 